\title{
Pengaruh Penggunaan Media Gambar dan Menulis Terpimpin terhadap Peningkatan Siswa dalam Keterampilan Menulis
}

\author{
Imam Purwanto Oktovan \\ Institut Agama Islam Negeri (IAIN) Syekh Nurjati Cirebon \\ Email :imam.purwantooktovan@gmail.com \\ Muhsin Riyadi \\ Institut Agama Islam Negeri (IAIN) Syekh Nurjati Cirebon \\ Email: ucin@yahoo.com \\ Masri'ah \\ Institut Agama Islam Negeri (IAIN) Syekh Nurjati Cirebon \\ Email :masriah057@gmail.com
}

\begin{abstract}
Abstrak
Penelitian ini bertujuan untuk mengetahui seberapa besar pengaruh penggunaan media gambar dan menulis terpimpin terhadap peningkatan siswa dalam keterampilan menulis (maharah kalam) di kelas X IIK MA NU Patrol Indramayu. Serta Salah satu faktor yang mempengaruhi berhasil tidaknya suatu pembelajaran adalah guru.Oleh karena itu, guru harus pandai memilih media dan metode yang tepat dan sesuai agar tujuan pembelajaran yang diharapkan dapat tercapai dengan maksimal.Salah satu alternative yang digunakan adalah dengan menerapkan mediagambar dan menulis terpimpindalam pembelajaran kemampuan menulis (maharat kitabah).Bahwasanya media gambar dan menulis terpimpinmerupakan media pembelajaran yang di arahkan untuk mempermudah siswa dalam memahami pembelajaran.Dan juga merupakan media dan metode yang efektif, karena media dan metode ini mampu memberikan pemahaman bagi siswa dan membuat mereka lebih semangat lagi dalam belajar khususnya dalam pembelajaran kemampuan keterampilan menulis. Penelitian ini menggunakan metode kuantitatif dengan jenis metode pre experiment design dengan analisis one group pre test-post test design. Metode pengumpulan data dalam penelitian ini adalah dengan cara observasi, tes, dan dokumentasi sedangkan analisis data dalam penelitian ini adalah dengan menggunakan, uji normalitas, uji homogenitas uji $\mathrm{t}$ tes dan uji hipotesis. Penelitian ini menyimpulkan bahwa terdapat pengaruh penggunaan media gambar dan metode
\end{abstract}


menulis terpimpin terhadap peningkatan kemampuan siswa dalam keterampilan menulis.

\section{Kata Kunci: Gambar, Menulis Terpimpin, Keterampilan menulis}

\section{Abstract}

The purpose of this researchhow much influence the use of Image media and guided writing Methode to increase student Writing Skills in learning Arabic in class XII K MA NU Patrol Indramayu. And One of the factors that influence the success or failure of learning is the teacher. Therefore, teachers must be clever in choosing the right methods so that the expected learning objectives can be achieved to the maximum. One alternative that is used is to apply Image media and guided writing method in Writing learning. That picture media is one of the learning media that is directed to facilitate students in understanding learning. And Image media and guided writing method is an effective method, because this method able to provide understanding for students and make them even more enthusiastic in learning, especially in Writing Skills learning. This research uses quantitative methods with the type of pre experiment designmethods with analysis one group pre test-post test. Data collection methods in this study are by observation, tests and Documentation, while data analysis in this study is to use, normality test, homogeneity test $t$ test and hypothesis test. The results of this study are that there is an influence of the use of Image media and guided writing method to increase ability students in the Writing Skills.

\section{Keywords: Pictures, Guided Writing, Writing Skills}

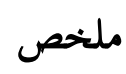

يهدف هذا البحث إلى تحديد مدىاستخدام وسائل الصورة والإنشاء الموجه لترقية الطلاب على مهارة الكتابة في الفصل العاشر IIK بمدرسة نهضة العلماء الثانوية الإسلامية باترول

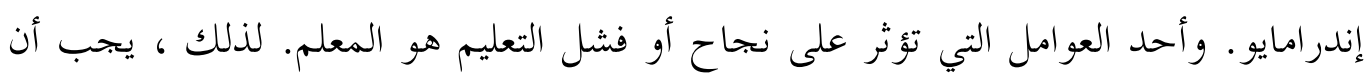

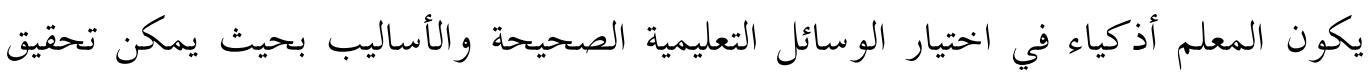

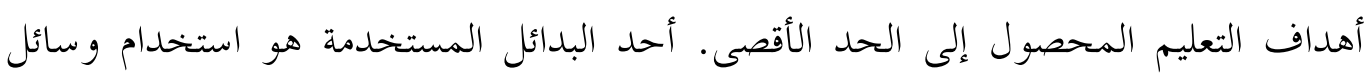

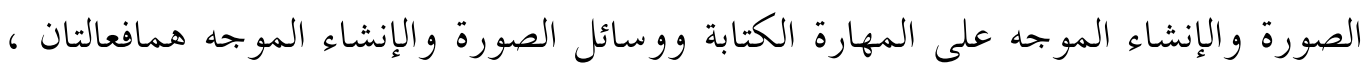
لأن هذه وسيلة والطريقة قادرتان على توفير قدرة للطلاب وجعلهم أكثر نشاطا في التعليم ، 


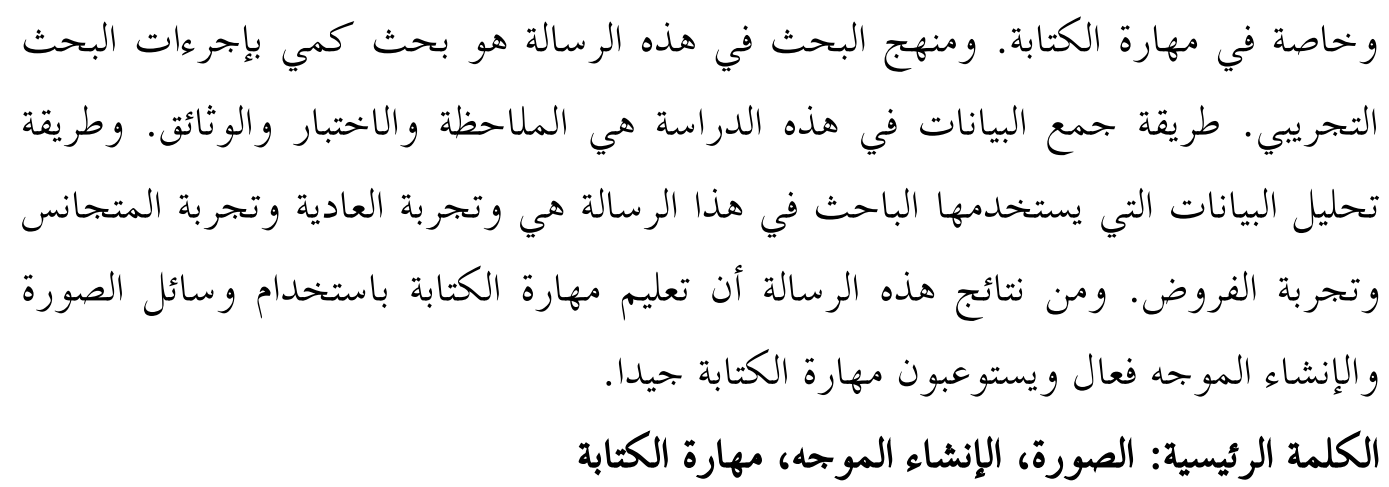

\section{Pendahuluan}

Materi pembelajaran bahasa Arab merupakan salah satu bahasa asing yang dijadikan materi mutlak dalam kurikulum satuan pendidikan berbasis islam negeri maupun swasta ${ }^{1}$.Dalam pemerolehan keterampilan berbahasa, kita biasanya melalui hubungan urutan yang teratur,mulamula pada masa kecil, kita belajar menyimak/mendengarkan bahasa, kemudian menulis, sesudah itu kita belajar membaca dan menulis. ${ }^{2}$

Pembelajaran bahasa Arab bertujuan agar para siswa dapat menguasai keempat keterampilan berbahasa yaitu; keterampilan mendengarkan,berbicara,membaca dan menulis. Serta mampu menggunakannya untuk berkomunikasi secara sederhana. ${ }^{3}$ Pelajaran bahasa arab merupakan pelajaran yang dianggap sulit oleh siswadalam kegiatan belajar, tidak semua anak didik yang diajar mempunyai kemampuan untuk berkonsentrasi dalam waktu yang relatife lama. Daya tangkap antara peserta didik yang satu dengan yang lain berbeda. Dalam hal ini Guru mempunyai peranan penting dalam suatu proses pendidikan.

Keterampilan menulis tidak bisa di pelajari secara otomatis, melainkan harus ada latihan dan pembiasaan yang dilakukan secara terus menerus, terlebih dalam pembalajaran bahasa arab yang notabene merupakanbahasa asing bagi siswa, mereka menganggap bahwa salah satu materi pembelajaran yang paling sulit adalah ketika pembelajaran

${ }^{1}$ Abdul Wahab Rosyidi, Media Pembelajaran Bahasa Arab. (Malang: UIN Malang Press, 2009). Hal.16. 2008). Hal. 1.

2Tarigan, Menulis sebagai suatu Keterampilan berbahasa. (Bandung: Angkasa,

3 A Chaeadar Alwasilah, Metodologi Pembelajaran Bahasa Arab. (Bandung: PT Remaja Rasdakatrya, 2011). Hal. 20. 
keterampilan menulis. Dan hal itu kuatkan oleh Iskandarwasid bahwa ketrampilan menulis merupakan yang paling sulit di bandingkan dengan tiga keterampilan lainya bahkan menurut penutur aslinya sendiri. ${ }^{4}$

Berdasarkan pengamatan lapangan yang dilakukan oleh peneliti selama melaksanakan kegiatan Praktek mengajar menggantikan guru pengampu dalam proses pengajaran selama bulan februari sampai dengan april tahun 2019 di MA NU Patrol Indramayu. Peneliti mengadakan ulangan di setiap akhir materi pembelajaran bahasa Arab, dengan KKM (Kriteria Ketuntasan Minimal) 76,hasil ulangan tersebut menunujukan bahwa rata - rata siswa kelas X IIK yang berjumlah 20 siswa, nilai pada keterampilan menulisnya sangat kecil,jika di bandingkan dengan keterampilan yang lainnya. Adapun capaian nilai rata-rata ulangan setiap keterampilannya sebagai berikut:

\begin{tabular}{|l|l|l|l|}
\hline No & Keterampilan & Persentase & Siswa Lulus \\
\hline 1 & Mendengarkan & $60 \%$ & 12 Siswa \\
\hline 2 & Berbicara & $55 \%$ & 11 Siswa \\
\hline 3 & Membaca & $85 \%$ & 17 Siswa \\
\hline 4 & Menulis & $25 \%$ & 5 Siswa \\
\hline
\end{tabular}

Dan ketika di wawancarai beberapa siswa terkait hasil ulangan harian tersebut,mengenai faktor apa yang menyebabkan mayoritas ulangan harian mereka tidak memenuhi KKM. Mereka mengeluhkan karena kurang menariknya pembelajaran khususnya pada keterampilan menulis dan mereka merasakan bahwa pembelajaran bahasa arab membosankan dengan tanpa adanya media pembelajaran.

Oleh karena itu peran media dalam pembelajaran sangat penting sekali. Adapun media pembelajaran adalah alat dan perlengkapan yang di gunakan oleh guru umtuk memfasilitasi dan meningkatkan proses pembelajaran. Hal ini mendidik guru untuk menggunakan karyanya dan siswa mudah dalam pembelajaran. ${ }^{5}$ Media pembelajaran memiliki banyak jenis, salah satunya adalah media gambar, definisinya adalah sarana visual, dan tujuannya untuk memberikan efektivitas pendidikan antara murid dan guru di kelas. Hal ini menjadi sarana yang paling penting bagi siswa untuk memahami pelajaran yang di terima dari guru,

${ }^{4}$ Iskandarwassid, Strategi Pembelajaran Bahasa. (Bandung: PT. Remaja Rosda Karya Offset, 2011) Hal. 97.

${ }^{5}$ Naif Ma'ruf, Karakteristik dan Metode Pembelajaran Bahasa Arab. (Beirut: Darun Nafsi, 1985). Hal. 230. 
karena kebanyakan siswa menyukai gambar, dan sarana visual ini berupa gambar. ${ }^{6}$

Berdasarkan uraian di atas peneliti merasa tertarik untuk Eksperimentaltasi dengan media gambar dan metode menulis terpimpin untuk mengembangkan atau meningkatkan kemahiran menulis (Alkitabah) bahasa Arab di MA NU Patrol Indramayu dan memilih judul“Pengaruh Penggunaan Media gambar dan metode menulis terpimpin Terhadap Peningkatan Kemampuan Maharah Al-kitabah Dalam Pembelajaran Bahasa Arab Siswa Kelas XMA NU Patrol Kabupaten Indramayu.

\section{Metode Penelitian}

Penelitian dengan judul “ Pengaruh Penggunaan Media gambar dan menulis terpimpin Terhadap Peningkatan Kemampuan Siswa Dalam Kemahiran Menulis (Study Eksperimental di kelas X IIK siswa MA NU Patrol Indramayu)merupakan penelitian kuantitatif dan menggunakan jenis penelitian Pre Eksperiment Design. Desain yang digunakan dalam riset ini adalah One Group Pre Test-Post Test Design. Desain ini di lakukan dalam satu kelas dengan melakukan pretest dan posttest, sehingga pengaruh treatment dapat dihitung dengan cara membandingkan nilai kelas saat di lakukan pre test dan post test. ${ }^{7}$ Desain ini dapat digambarkan sebagai berikut:

$\mathrm{O}_{1}=$ nilaipretest

\section{$\mathrm{O}_{1} \quad \mathrm{X} \quad \mathrm{O}_{2}$}

$\mathrm{O}_{2}=$ nilai posttest

$\mathrm{X}=$ perlakuan (treatment), dengan menggunakan media gambar dan metode menulis terpimpin.

Penelitian ini telah dilakukan dalam dua tahap yaitu pemberian tes awal (pretest) dan pemberian tes akhir (posttest). Pemberian tes awal dimana pada tahap ini tanpa diberikan perlakuan.Pemberian tes akhir diberikan perlakuan ditandai dengan X. Keduanya untuk mengetahui pengaruh kemampuan keterampilan menulis (maharah kitabah) sebelum

${ }^{6}$ Ulin Nuha, Metodologi Super Efektif Pembelajaran Bahasa Arab. (Yogyakarta: Diva Press, 2012). Hal. 98.

7 Sugiono, Metode Penelitian Pendidikan Pendekatan Kuantitatif dan RED (Bandung: PT Alpabeta, 2015). 
dan sesudah menggunakan media gambar dan metode menulis terpimpin terhadap kemampuan siswa dalam keterampilan menulis. Penelitian ini dilaksanakan pada siswa kelas XIIK MA NU Patrol Indramayu.

Populasi adalah suatu wilayah generalisasi yang tersusun atas subyek maupun obyek yang memiliki kualitas dan ciri-ciri tertentu yang dipatenkan peneliti untuk dipahami dan dipelajari serta dibentuk sebuah kesimpulan. Populasi yang dipilih dalam penelitian ini yaitu seluruh siswa kelas X IIKMA NU Patrol Indramayu tahun ajaran 2019 / 2020. Jumlah seluruh siswa kelas X IIK yaitu 20 siswa.

Hatch dan Farhady, 1981 dalam Sugiyono mengatakan bahwa variabel merupakan suatu atribut yang dimiliki sebuah obyek atau seseorang yang memiliki sebuah variasi di antara satu orang dengan orang yang lain dan bisa dikatakan satu obyek dengan obyek yang lain.

Kerlinger 1973 dalam Sugiono menjelaskan bahwa variabel merupakan sifat maupun konstrak yang nantinya akan dipelajari. Contoh dari variabel ini misalnya tingkat aspirasi, pendidikan, status sosial, penghasilan, golongan gaji, produktivitas kerja, jenis kelamin dan lain sebagainya. Kerlinger juga menjelaskan bahwa suatu variabel dikatakan sebagai sifat yang akan diambil dari nilai yang berbeda. Maka dari itu variabel bisa dikatakan sesuatu yang bervariasi. Untuk pendapat selanjutnya yaitu dari Kidder, mengatakan bahwa suatu variabel adalah sebuah kualitas yang mana peneliti akan mempelajari dan menarik kesimpulan darinya.

Pada penelitian ini teknik pengumpulan data dapat diukur dengan adanya ketercapaian aspek dan penilaian yang digunakan sebagai data hasil dari penelitian dalam bentuk isntrument penelitian sebagai berikut:

Lembar tes yang digunakan pada penelitian ini terdapat dua jenis tes yaitu pretest dan posttest untuk mengetahui sejauh mana kemampuan siswa dalam keterampilan menulis bahasa arab. Pada lembar tes terdapat gambaruntuk di uraikan kedalam sebuah tulisan karangan yang terpimpin oleh guru.

Teknik pengumpulan data yang dilakukan dalam penelitian ini akan diperoleh dari hasil pengumpulan data yang menggunakan teknik tes, dokumentasi dan observasi langsung. Teknik tes bertujuan untuk mengetahui sejauh mana kemampuan pemahaman siswa dalam penyusunan sebuah kalimat sempurna dalam teks bahasa arab. Tes 
dilaksanakan sebanyak dua kali, yaitu pretest dan posttest. Pretest digunakan untuk mengetahui kemampuan awal siswa terhadap pemahaman siswa dalam penulisan kalimat sempurna dalam teks bahasa arabsebelum mendapatkan perlakuan. Sedangkan posttest digunakan untuk mengetahui pemahaman siswa setelah mendapatkan perlakuan. Teknik observasi dilakukan untuk mengamati pelaksanaan kegiatan pembelajaran bahasa arab dengan menggunakan media gambar dan metode menulis terpimpin pada satu kelas secara langsung. Teknik observasi juga dilakukan untuk mengamati penelitian sebagai guru pelaksana pembelajaran ketika melaksanakan kegiatan pembelajaran, pengamatan dilakukan oleh guru.

Teknik analisis data ini diperoleh setelah semua data terkumpul dan akan dianalisis sehingga diperoleh hasil yang diperlukan dalam penelitian ini. Pada penelitian ini analisis data instrument menggunakan uji validitas dan uji realibilitas dan uji t test.Uji validitas adalah suatu ukuran yang menunjukan tingkat kevalidan dan kesahihan suatu instrument. Suatu instrument dikatakan valid apabila dapat mengungkap data dari variabel yang diteliti secara cepat.Validitas dalam penelitian ini diukur menggunakan program pengolahan data SPSS dengan korelasi Product Moment. Kriteria item yang valid yaitu dengan melihat hasil probabilitas. Jika nilat thitung $>$ tabel maka item dinyatakan valid.Jika thitung $<$ tabel maka item dinyatakan tidak valid.

Uji realibilitas menunjuk pada suatu pengertian bahwa suatu instrument cukup dapat di percaya untuk digunakan sebagai alat pengumpul data karena instrumen sudah baik. Item yang valid akan dilakukan perhitungan realibilitas dengan menggunakan rumus Cronbach's Alpha dengan tujuan mencari koefesien realibilitasnya. Realibilitas dari skala ini diketahui dengan menggunakan program SPSS. Uji realibilitas dengan teknik Cronbach's Alpha yaitu dengan cara menentukan nilai varian tiap butir pertanyaan, menentukan nilai varian total dan menentukan realibilitas instrument.

$\mathrm{r}_{11}=\left(\frac{\mathrm{k}}{(\mathrm{k}-1)}\right)\left(1-\frac{\sum \sigma_{\mathrm{b}}^{2}}{\sigma_{\mathrm{t}}^{2}}\right)$

Kriteria uji realibilitas dalam rumus Cronbach's Alpha menggunakan batasan 0,6. Jika realibilitas $<0,6$ maka kurang baik, jika realibilitas 0,7 dapat diterima dan jika realibilitas $>0,8$ maka baik. 
Uji normalitas berguna untuk mengetahui setiap sampel yang akan digunakan berasal dari populasi yang terdistribusi normal atau tidak normal. Uji normalitas data pada penelitian ini dilakukan dengan menggunakan program pengolahan data SPSS melalui uji normalitas Kolmogorov-Smirnov dengan kriteria jika signifikansi $>0,05$ maka data berdistribusi normal, dan jika signifikansi $<0,05$ maka data tidak berdistribusi normal.

Uji homogenitas dilakukan pada hasil data pretest dan posttest siswa. Pada penelitian ini, uji homogenitas dilakukan dengan menggunakan program pengolahan data SPSS melalui Levene. Kriteria pengujiannya adalah apabila nilai signifikansi atau probabilitas $<0,05$ maka data tidak homogen, sedangkan jika nilai signifikansi atau nilai probabilitas $>0,05$ maka data homogen. ${ }^{8}$

Uji hipotesis pada penelitian ini menggunakan teknik t-test. Teknik ini merupakan teknik statistik yang dipergunakan untuk menguji signifikansi perbedaan dua buah mean yang berasal dari dua buah mean distribusi (Winarsunu, 2015:75). Data yang diperoleh dalam penelitian ini berjenis rasio dan digunakan untuk mengetahui perbedaan nilai pretest dan posttest, perhitungannya menggunakan uji t-test. Uji t-test ini nantinya akan dijadikan pembanding antara kelas Eksperimental tanpa menggunakan perlakuan dan kelas Eksperimental menggunakan perlakuan. Adanya alasan menggunakan uji t-test ini yaitu karena tidak adanya keterkaitan antara sampel yang digunakan. Maksudnya yaitu perlakuan yang terdapat pada kelas Eksperimental melalui perlakuan pretest dan posttest. Uji t-test pada penelitian ini dilakukan dengan menggunakan program pengolahan data SPSS dengan rumus Indipendent Samples T-Test.

\section{Media Gambar}

1. Pengertian Media Gambar

Secara harfiah kata media berasal dari latin" medium" yang berarti peranta, sedangkan dalam bahasa Arab media bersal dari kata wasaaila artinya pengatar pesan dari pengiriman kepada penerima pesan.Tujuan utama media pembelajaran untuk menambah kejelasan pengertian, mempelancar proses pembelajaran, mempermudah proses pencapaian tujuan

8 Arikunto Suharsimi, Prosedur Penelitian suatu Pendidikan Praktik. (Jakarta: Rineka Cipta, 2013). Hal. 221. 
pendidikan. Sedangkan tujuan sampingannya yaitu motivasi dan membangkitkan minat, memusatkan perhatian dan memungkinkan siswa untuk belajar secara individu ataupun kelompok. ${ }^{9}$

Ada beberapa kriteria yang patut diperhatikan dalam memilih media, yaitu sebagai berikut:

a. Sesuai dengan tujuan yang ingin dicapai. Tujuan ini dapat digunakan dalam bentuk tugas yang harus dikerjakan oleh siswa seperi menghafal

b. Tempat untuk mendukung isi pelajaran yang sifatnya fakta, konsep, prinsip atau generalisasi.

b. Praktis, luwes dan bertahan

c. Guru terampil menggunakannya

d. Pengelompokan sasaran. ${ }^{10}$

Media gambar yang baik adalah media gambar yang sesuai dengan tujuan pembelajaran. Selain itu ada beberapa syarat yang perlu diperhatikan antara lain:

a. Autentik yaitu gambar tersebut harus secara jujur melukiskan situasi seperti ketika orang melihat benda sebenarnya.

1 Sederhana yaitu komposisi gambar hendaknya cukup jelas menunjukkan poin-poin pokok pada gambar.

c. Ukuran relatif yaitu gambar dapat membesarkan atau memperkecil objek/benda sebenarnya.

d. Gambar sebaiknya mengandung gerak atau perbuatan yang memperlihatkan aktifitas tertentu.

e. Gambar yang bagus belum tentu baik untuk mencapai tujuan pembelajaran. Walaupun dari segi mutu kurang, gambar karya siswa seringkali lebih baik.

a Tidak setiap gambar yang bagus merupakan media yang bagus. Sebagai media yang baik, gambar hendaklah bagus dari sudut seni dan sesuai dengan tujuan pembelajaran yang ingin dicapai

a. Fungsi Media Gambar

9 Abdul Hamid, Pembelajaran Bahasa Arab, Pendekatan, Metode, dan Materi.( Malang: UIN Malang Press, 2008). Hal. 181.

${ }^{10}$ Hilmi, Efektivitas Penggunaan Media Gambar Dalam Pembelajaran Bahasa Arab dalam Lantanida Journal Vol. 4. No. 2, 2016. Hal. 130. 
Fungsi media pada mulanya dikenal sebagai alat bantu dalam kegiatan belajar mengajar, yakni memberikan pengalaman visual pada anak dalam rangka kompleks dan abstrak menjadi lebih sederhana, kontret dan mudah dipahami.Fungsi media gambar dalam kegiatan belajar mengajar tidak lagi peraga guru melainkan pembawa informasi atau pesan pembelajaran yang dibutuhkan siswa. Hal demikian pusat guru berpusat pada pengembangan dan pengolahan individu dan kegiatan belajar mengajar ${ }^{11}$

Sebagai seorang pendidik, fungsi dan kemapuan media sangat penting.Media merupakan integral dari system pembelajaran sebagai dasar kebijakan dalam pemilihan, pengembangan maupun pemanfaatan. Sedangkan fungsi media gambar dalam sebagai berikut:

b. Fungsi afektif

Media visual dapat terlihat dari tingkat kenikmatan siswa ketika belajar ( atau membaca) teks yang bergambar. Gambar atau lambang visual

dapat menggugah emosi dan sikap siswa, misalnya informasi yang menyangkut masalah sosial atau ras.

a. Fungsi kognitif

Media visual terlihat dari temuan-temuan penelotian yang mengungkapkan bahwa lambang visual atau ganbar mempelancar pencapain tujuan memahi dan mengingat informasi atau pesan yang terkandung dalam gambar.

b. Fungsi kompensatori

Media pembelajaran terlihat dari hasil penelitian bahwa media visual yang memberikan konteks untuk memahi teks membantu siswa yang lemah dalam membaca untuk mengorganisasikann informasi dalam teks dan mengingatkanya kembali. Dengan kata lain, media pembelajaran berfungsi untuk mengakompdasikan siswa yang lemah dan lambat menerima dan memahami isi pelajaran yang disajikan dengan teks atau disajikan secara verbal

11 Sholihah, Penggunaan Media Gambar dalam Pembelajaran Mufrodat dalam Jurnal Tarling, Vol. 1, No.1, 2012. Hal. 69. 
Media gambar merupakan salah satu teknik media pembelajaran yang efektif karena mengkombinasikan fakta dan gagassan secara jelas, kuat dan terpadu melalui pengungkapan kata-kata dan gambar. Media gambar terbagi atas:

b. Gambar Jadi

Gambar jadi merupakan gambar-gambar dari majalah, brosur, selebaran dan lain-lain.Gambar yang dikumpulkan sdan dipilih untuk digunakan dalam penyampaian materi pelajaran sebaiknya difoto copy, kemudian gambar-gambar digabung dengan label judul dengan huruf-huruf lekat. Hasilnya dapat difotocopy atau difoto kemudian dicetak diatas kertas fotografi yang baik dengan ukuran yang diinginkan

a. Gambar garis

Gambar garis merupakan gambar sederhana yang dapat dibuat sendiripada papan tulis ketika berada dikelas atau dipersiapkan lebih dahulu pada lembaran karton atau kertas yang sesuai.Gambar garis dapat digunakan pada media flashcard (kartu kecil yang berisi gambar, teks, atau tanda simbol yang mengingatkan gambar itu).Kartu-kartu tersebut menjadi petunjuk dan rangsangan bagi siswa untukmemberikan respons yang diinginkan. ${ }^{12}$

Dan dalam penerapannya, media gambar mempunyai kelebihan, diantaranya adalah:

a. Sifatnya konkret, gambar lebih realistis menunjukkan pokok masalah dibandingkan dengan media verbal semata.

b. Gambar dapat mengatasi batasan ruang dan waktu.

c. Media gambar dapat mengatasi keterbatasan pengamatan kita.

d. Gambar dapat memperjelas suatu masalah, dalam bidang apa saja dan untuk tingkat usia berapa saja sehingga dapat mencegah atau membetulkan kesalahpahaman.

e. Gambar harganya urah dan gampang didapat serta digunakan tanpa memamerkan peralatan khusus.

Selain kelebihan-kelebihan tersebut, gambar mempunyai beberapa kelemahan, yaitu:

1. Gambar hanya menekankan persepsi indera mata.

${ }^{12}$ Azhar Arsyad, Media Pembelajaran. (Jakarta: Rajawali Press, 2013). Hal. 115. 
2. Gambar benda yang terlalu kompleks kurang efektif untuk kegiatan pembelajaran.

3. Ukurannya sangat terbatas untuk kompleks besar

4. Meskipun media gambar mempunyai beberapa kelemahan, tetapi media gambar tetap merupakan media yang paling umum dipakai, yang dimengerti dan dinikmati dimana saja.

\section{Pengertian Menulis Terpimpin (Insya Muwajah)}

Menulis Terpimpin (Insya Muwajah) adalah pengarahan karangan oleh seorang guru dengan menginstruksikan siswa untuk memikirkan sesuatu dan kemudian mengekspresikan ide. Adapun menulis terpimpin menurut Ma'ruf adalah arahan sistematis guru sesuai dengan materi terpadu untuk mencapai tingkat yang di tentukandalam menerjemahkan pikiran, perasaan, pengamatan, dan pengalaman secara verbal dan menulis dalam bahasa yang baik menurut konsistensi intelektual tertentu. ${ }^{13}$ Adapun Arahan yang ditentukan disebut menulis terpimpin (Insya Muwajah) karena kegiatan siswa terbatas pada apa yang diberikan oleh guru. ${ }^{14}$

Tujuan menulis terpimpin, seperti dikutip Arifa (2010) sebagai berikut:

1) Kemampuan untuk mengartikulasikan ide menggunakan kata-kata yang tepat dan gaya yang sesuai

2) Kemampuan untuk mengoordinasikan bagian-bagian dari ide yang diekspresikan dengan apa yang digambarkan sebagai pengaruh yang sesuai untuk di tuliskan.

3) Kemampuan individu untuk menyampaikan sudut pandang orang lain dan mengekspresikannya secara tertulis.

\section{Keterampilan menulis}

Tulisan atau menulis (al-kitabah) merupakan salah satu sarana berkomunikasi antara seseorang dengan yang lainnya, sama halnya dengan menyimak atau mendengar (al-istima'), berbicara (al-kalam), dan membaca (al-qiro'ah). Ia merupakan suatu keniscayaan sosial dalam rangka mentransfer hasil pemikiran atau memahami pemikiran orang lain meski dengan jarak waktu dan tempat. ${ }^{15}$

${ }^{13}$ Ma'ruf Nayif Mahmud, Khoshoisil 'Arabiyyah Watadrisiha. (Beirut: Libanon, 1985). Hal. 105.

${ }^{14}$ Acep Hermawan, Metodologi Pembelajaran Bahasa Arab. (Bandung: PT Rosada Karya Offset). Hal. 75.

${ }^{15}$ Rusydi Ahmad Tha'imah, Keterampilan Berbahasa. (Al-Qahiroh: Dar Al Fiqry Al-'Aroby, 1996). Hal. 186. 
Secara etimologi, kata kitabah dalam bahasa arab merupakan bentuk masdar dari kata كتابة - يكتب - كتب yang artinya tulis, menulis dan tulisan. ${ }^{16}$ Sedangkan menurut terminologi, kitabah adalah kemampuanuntuk mengetahui simbol-simbol tulisan dan pemahaman dalammerangkainya satu kata yang menekankan indera penglihatan.

Al-kitabah (tulisan) dalam bahasa arab mencakup tiga hal : khat,imla' dan ta'bir, hal tersebut merupakan simbol-simbol yang dipakaiuntuk mengungkapkan hasil-hasil pikiran dengan tulisan. Bila dilhat darisisi adanya sebagai rasm imla'iy (model atau bentuk huruf) maka itu dinamakan imla', dan jika dilihat dari sisi adanya sebagai ta'bir uslubiyyang mengungkap pikiran penulis maka ia dinamakan ta'bir. ${ }^{17}$

Adapun yang dimaksud dengan maharah al-kitabah (kemahiranatau keterampilan menulis), adalah: kemampuan untuk mengaplikasikan apa yang dibaca dan didengar kedalam bentuk tulisan melalui rumus/susunan kata sehingga dapat dibaca dan dipahami. Kemahiran atau keterampilan menulis merupakan kemahiran terakhir yang harus dikembangkan setelah kemahiran menyimak, berbicara, dan membaca. Bahkan dikatakan bahwa keterampilan menulis merupakan keterampilan tertinggi dari empat keterampilan berbahasa tersebut.

Keterampilan menulis merupakan kegiatan produktif danekspresif untuk mengungkapkan ide, pikiran, gagasan, dan pengetahuan. Dalam kegiatan menulis ini, penulis haruslah terampil memanfaatkan grafologi, struktur bahasa, dan kosakata. Disebut sebagai kegiatan produktif karena kegiatan menulis menghasilkan tulisan, dan disebut kegiatan ekspreisf karena kegiatan menulis adalah kegiatan yang mengungkapkan ide, gagasan, pikiran dan pengetahuan penulis kepada pembaca. ${ }^{18}$

Menurut peck \& schulz (dalam Tarigan, 1982) mengemukakantujuan menulis sebagai berikut:

1. Membantu para peserta didik memahami bagaimana cara ekspresitulis dapat melayani mereka, dengan jalan menciptakan

16 Atabik Ali dan Ahmad Zuhri Muhdhor, Kamus Kontemporer Arab-Indonesia, Cet.I. (Yogyakarta: Yayasan Ali Maksum,1996). Hal. 1493.

${ }^{17}$ Mahmud Ali Al-Samman, At-Taujih fi Tadris al-Lughah al-'Arabiyah. (Kairo: Dar Al-Ma'arif, 1983). Hal. 224.

18 Henry Guntur Tarigan, Menulis Sebagai Suatu Keterampilan Berbahasa. (Bandung: Angkasa, 1982). Hal. 3-4. 
situasisituasi di dalam kelas yang jelas memerlukan karya tulis dankegiatan menulis.

2. Mendorong para peserta didik mengekspresikan diri secara bebasdalam tulisan

3. Mengajar para peserta didik menggunakan bentuk yang tepat danserasi dalam ekspresi tulis.

4. Mengembangkan pertumbuhan bertahap dalam menulis dengan caramembantu para peserta didik menulis sejumlah maksud dengansejumlah cara penuh keyakinan pada diri sendiri secara bebas.

\section{Pengaruh Penggunaan Media Gambar Dan Menulis TerpimpinTerhadap Peningkatan Kemampuan Siswa Dalam Keterampilan Menulis (Maharat Kitabah)}

Pada tes ini dimulai dengan memberikan pretest di kelas.Waktu yang diberikan kepada siswa sekitar 45 menit. Setelah dilaksanakan pretest, peneliti melaksanakan pembelajaran bahasa arabtanpa menggunakan media gambar dan metode menulis terpimpin. Setelah pembelajaran selesai dan untuk mengetahui kemampuan pemahaman siswa peneliti melakukan posttest untuk mengetahui perbedaan kemampuan pemahaman siswa sebelum dan sesudah pembelajaran menggunakan media gambar dan metode meulis terpimpin. Adapun hasilnya sebagai berikut:

\section{Statistics}

\begin{tabular}{|c|c|c|c|}
\hline & & Pre-test & Post-test \\
\hline \multirow{2}{*}{$\mathrm{N}$} & Valid & 20 & 20 \\
\hline & Missing & 0 & 0 \\
\hline \multicolumn{2}{|c|}{ Mean } & 73,35 & 87,40 \\
\hline \multicolumn{2}{|c|}{ Std. Error of Mean } & 1,548 & 1,473 \\
\hline \multicolumn{2}{|c|}{ Median } & 75,00 & 90,00 \\
\hline \multicolumn{2}{|c|}{ Mode } & 75 & 90 \\
\hline \multicolumn{2}{|c|}{ Std. Deviation } & 6,923 & 6,589 \\
\hline \multicolumn{2}{|c|}{ Variance } & 47,924 & 43,411 \\
\hline \multicolumn{2}{|c|}{ Skewness } &,- 054 &,- 781 \\
\hline \multicolumn{2}{|c|}{ Std. Error of Skewness } &, 512 & ,512 \\
\hline \multicolumn{2}{|c|}{ Kurtosis } &,- 537 &,- 215 \\
\hline
\end{tabular}




\begin{tabular}{|l|r|r|} 
Std. Error of Kurtosis &, 992 &, 992 \\
Range & 23 & 22 \\
Minimum & 62 & 73 \\
Maximum & 85 & 95 \\
Sum & 1467 & 1748 \\
\hline
\end{tabular}

Diketahui hasil perhitingan SPSS dari nilai pretest di kelas tersebutyaitumedian 75.00denganrata-rata73,35, maksimum 85,00 dan minimum 62,00. Sedangkan dari nilai posttestdi kelas tersebut yaitudengannilaimedian 90.00denganrata-rata 87,40, maksimum 95,00 dan minimum 73,00.

\section{Uji Normalitas}

Uji normalitas berguna untuk mengetahui setiap sampel yang akan digunakan berasal dari populasi yang terdistribusi normal atau tidak normal. Uji normalitas data pada penelitian ini dilakukan dengan menggunakan program pengolahan data SPSS melalui uji normalitas Kolmogorov-Smirnov dengan kriteria jika signifikansi $>0,05$ maka data berdistribusi normal, dan jika signifikansi $<0,05$ maka data berdistribusi tidak normal. Adapun hasil uji normalitas pada penelitian ini sebagai berikut:

Tests of Normality

\begin{tabular}{|c|c|c|c|c|c|c|}
\hline \multirow{2}{*}{ Kelas X } & \multicolumn{3}{|c|}{ Kolmogorov-Smirnova } & \multicolumn{3}{|c|}{ Shapiro-Wilk } \\
\hline & Statistic & Df & Sig. & Statistic & $\mathrm{df}$ & Sig. \\
\hline Pre-Test & , 180 & 20 & , 089 & ,922 & 20 & \\
\hline Post-Test & 203 & 20 & , 030 & ,909 & 20 & \\
\hline
\end{tabular}

Dari tabel di atas diketahui bahwa uji normalitas di kelas control pretest-posttest dan kelas ekperimen pretest-postest sebesar $(0,89>0,05)$ dan $(0,30>0,05)$. Hal ini dapat diketahui bahwa uji nomalitas berdistribusi normal.

\section{Uji Homogenitas}


Uji homogenitas dilakukan pada hasil data pretest dan posttest siswa. Pada penelitian ini, uji homogenitas dilakukan dengan menggunakan program pengolahan data SPSS melalui Levene. Kriteria pengujiannya adalah apabila nilai signifikansi

atau probabilitas $<0,05$ maka data tidak homogen, sedangkan jika nilai signifikansi atau nilai probabilitas $>0,05$ maka data homogen.

Test of Homogeneity of Variance

\begin{tabular}{|c|c|c|c|c|}
\hline & Levene Statistic & df1 & df2 & Sig \\
\hline Based on Mean & ,038 & 1 & 38 & \\
\hline Based on Median & ,010 & 1 & 38 & \\
\hline $\begin{array}{l}\text { Based on Median and } \\
\text { with adjusted df }\end{array}$ & ,010 & 1 & 37,937 & \\
\hline Based on trimmed mean & ,026 & 1 & 38 & \\
\hline
\end{tabular}

Dari tabel diatas diketahui bahwa uji Homogenitas dikelas sebesar $0,846>0,05$. Hal ini berarti dapat kita ketahui data berdistribusi Homogen.

\section{Uji Hipotesis}

Uji Hipotesis pada penelitian ini menggunakan teknik t-test. Teknik ini merupakan teknik statistik yang dipergunakan untuk menguji signifikansi perbedaan dua buah mean yang berasal dari dua buah distribusi.

Paired Samples Statistics

\begin{tabular}{|ll|r|r|l|lr|}
\hline & & Mean & N & $\begin{array}{l}\text { Std. } \\
\text { Deviation }\end{array}$ & $\begin{array}{l}\text { Std. } \\
\text { Mean }\end{array}$ & Error \\
\hline Pair 1 & Pre-Test & 73,35 & 20 & 6,923 & 1,548 \\
& Post-Test & 87,40 & 20 & 6,589 & 1,473 \\
\hline
\end{tabular}

Paired Samples Correlations

\begin{tabular}{|ll|r|r|r|}
\hline & N & Correlation & Sig. & \\
\hline Pair 1 & Pre-Test\&Post-Test & 20 &, 598 &, 005 \\
\hline
\end{tabular}

\section{Paired Samples Test}

\begin{tabular}{|l|l|l|}
$\mathrm{t}$ & $\mathrm{df}$ & Sig. (2- \\
\hline
\end{tabular}




\begin{tabular}{|l|l|l|l|l|l|l|l|r|}
\hline & Mean & $\begin{array}{l}\text { Std. } \\
\text { Devia } \\
\text { tion }\end{array}$ & $\begin{array}{l}\text { Std. } \\
\text { Error } \\
\text { Mea } \\
\mathrm{n}\end{array}$ & \multicolumn{2}{|l|}{$\begin{array}{l}\text { 95\% Confidence } \\
\text { Interval of the } \\
\text { Difference }\end{array}$} & Lower & Upper & tailed) \\
\cline { 1 - 7 } Pair 1 $\begin{array}{l}\text { Pre-Test } \\
\text { Post-Test }\end{array}$ & $-14,050$ & 6,065 & 1,356 & $-16,889$ & $-11,211$ & $-10,360$ & 19 &, 000 \\
\hline
\end{tabular}

\section{Kesimpulan}

Kemampuan siswa terhadap keterampilan menulis tanpa menggunakan media gambar dan metode menulis terpimpin pada nilai pretestyaitudengannilaiminimum62,00maksimum 85,00 median 75,00denganrata-rata73,53.Sedangkan dari nilai posttest yaitu dengan nilai minimum 73, maksimum 95, median 90.00 dengan rata-rata 87,40.

Terdapat pengaruh yang signifikan dari pemberian perlakuan terhadap kemampuan siswa terhadap keterampilan menulis dengan menggunakan media gambar dan metode menulis terpimpin. Hal ini dibuktikan dari perhitungan T-Test dengan menggunakan analisis SPSS. Hasil yang diperoleh dari perhitungan tersebut adalah nilai Sig. (2 tailed) sebesar 0,000. Hasil sig. ( 2 tailed) sebesar 0,000 yang berarti bahwa nilai ini lebih kecil dari 0,05 dimana dapat disimpulkan bahwa Ha diterima dan Ho ditolak.

\section{Daftar Pustaka}

A Chaedar Alwasilah. 2011. Metodologi Pembelajaran Bahasa Arab.(Bandung : PT Remaja Rasdakatrya)

Ali Al-Samman, Ahmad. 1983. Al-Taujih Fi Tadris Al-Lughah Al'Arabiyah.Kairo: Dar Al-Ma'arif)

Ali, Atabik dan Ahmad Zuhri Muhdhor. 1996. Kamus Kontemporer ArabIndonesia. Yogyakarta:Yayasan Ali Maksum.

Arsyad, Azhar. 2013. Media Pembelajaran. Jakarta: Rajawali Press.

Hamid, Abdul. 2008. Pembelajaran Bahasa Arab, Pendekatan, Metode, dan Materi. Malang: UIN Malang Press.

Hermawan, Acep. Metodologi Pembelajaran Bahasa Arab. Bandung: PT Rosada Karya Offset.

Hilmi. 2016. Efektivitas Penggunaan Media Gambar dalam Pembelajaran Bahasa Arab dalam Lantanida Journal Vol. 4. 
Iskandarwassid. 2011. Strategi Pembelajaran Bahasa. Bandung: PT. Remaja Rosda Karya Offset

Ma'ruf, Naif. 1985. Karakteristik dan Metode Pembelajaran Bahasa Arab. Beirut: Darun Nafsi.

Mahmud, Ma'ruf Nayif. 1985. Khoshoisil 'Arabiyyah Watadrisiha. Beirut: Libanon.

Nuha, Ulin. 2012. Metodologi Super Efektif Pembelajaran Bahasa Arab. Yogyakarta: Diva Press.

Rosyidi, Abdul Wahab. 2009. Media Pembelajaran Bahasa Arab. Malang: UIN Malang Press.

Sholihah. 2012. Penggunaan Media Gambar dalam Pembelajaran Mufrodat dalam Jurnal Tarling Vol. 1.

Sugiono. 2015. Metode Penelitian Pendidikan Pendekatan Kuantitatif dan $R \mathcal{E D}$. Bandung: PT Alpabeta.

Suharsimi, Arikunto. 2013. Prosedur Penelitian suatu Pendidikan Praktik. Jakarta: Rineka Cipta.

Tarigan, Henry Guntur. 1982. Menulis Sebagai Suatu Keterampilan Berbahasa. Bandung: Angkasa.

Tarigan. 2008. Menulis sebagai suatu Keterampilan Berbahasa. Bandung: Angkasa.

Tha'imah, Rusydi Ahmad. 1996. Keterampilan Berbahasa. Al-Qahiroh: Dar Al Fiqry $\mathrm{Al}^{\prime}$ Aroby. 